\title{
USULAN PREVENTIVE MAINTENANCE PADA MESIN KOMORI LS440 DENGAN MENGGUNAKAN METODE RELIABILITY CENTERED MAINTENANCE (RCM II) DAN RISK BASED MAINTENANCE (RBM) DI PT ABC
}

\author{
${ }^{1}$ Destina Surya Dhamayanti, ${ }^{2}$ Judi Alhilman, ${ }^{3}$ Nurdinintya Athari \\ 1,2,3Program Studi Teknik Industri, Fakultas Rekayasa Industri, Telkom University \\ 1'destina.s.dhamayanti@gmail.com, ${ }^{2}$ judi.alhilman@gmail.com, ${ }^{3}$ nurdinintya@telkomuniversity.ac.id
}

\begin{abstract}
Abstrak-PT ABC merupakan perusahaan cetak dalam skala nasional. Produk yang dihasilkan oleh perusahaan merupakan buku ajar, majalah, surat kabar, dan lain sebagainya. Kegiatan maintenance yang ada PT ABC terbagi menajadi dua, yaitu preventive maintenance setiap senin dan kamis serta kegiatan corrective maintenance yang dilakukan jika mesin mengalami kegagalan fungsi. Kegagalan fungsi pada mesin Komori masih cukup tinggi. Oleh karena itu, diperlukan kegiatan pecegahaan untuk meningkatkan reliabilitas mesin. Metode yang dilakukan adalah Reliability Centered Maintenance, yaitu dengan menganalisis failure yang terjadi dengan menggunakan analisis Failure Mode and Effect Analysis dan Decision Worksheet. Hasil dari analisis ini merupakan preventive task masing-masing komponen. Sedangkan untuk menganalisis risiko yang diakibatkan jika mesin mengalami gagal fungsi, yaitu dengan metode Risk Based Maintenance. Hasil yang diperoleh dari nilai risiko yang ditanggung perusahaan ketika mesin mengalami failure, yaitu sebesar Rp965.904.899,36. Berdasarkan hasil pengolahan data pada subsistem kritis diperoleh kesimpulan bahwa enam komponen dilakukan dengan task scheduled on condition, tiga komponen dengan task scheduled restoration, dan enam komponen dengan task scheduled discard. Sedangkan untuk interval waktu dalam pengerjaan preventive maintenance pada komponen tersebut disesuaikan dengan task yang diperoleh. Setelah mendapatkan interval waktu perawatan, kemudian ditentukan biaya perawatan usulan yang dikeluarkan perusahaan, yaitu sebesar Rp971.567.519,69.
\end{abstract}

Kata kunci: Corrective Maintenance, Decision Worksheet, Failure Mode and Effect Analysis, Preventive Maintenance, Reliability Cencetered Maintenance, Risk Based Maintenance

\section{PENDAHULUAN}

Maintenance merupakan sebuah kegiatan untuk mengembalikan fungsi dari mesin atau sistem ke fungsi normal. Kegiatan maintenance sering dilakukan pada pabrik yang memiliki mesin-mesin besar. Sebagai contoh pada perusahaan perusahaan cetak.
PT ABC merupakan perusahaan cetak dalam skala nasional. Produk yang dihasilkan oleh perusahaan merupakan buku ajar dari SD, SMP, SMA, majalah, surat kabar, dan lain sebagainya. Jumlah produksi PT ABC dari tahun 2010 - 2013 mengalami kenaikan. Namun pada tahun 2014 produksi PT ABC mengalami penurunan. Penurunan ini terlihat dari jumlah produksi hanya sebesar $78 \%$ dari produksi yang direncanakan. Penurunan jumlah produksi ini diakibatkan oleh sering terjadinya kerusakan pada mesin. Kegagalan fungsi pada mesin sering terjadi sehingga membuat mesin berhenti bekerja.

Proses produksi PT ABC terdiri dari proses pracetak, cetak sheet, cetak web, dan finishing. Fokus penelitian ini yaitu pada proses cetak terutama cetak sheet. Pemilihan ini dikarenakan proses cetak sheet merupakan proses yang cukup berpengaruh pada penjualan produk karena proses ini membuat cover untuk buku. Cover buku merupakan salah satu unsur pertama dilihat ketika membeli sehingga bagian cover memerlukan cetakan yang bagus.

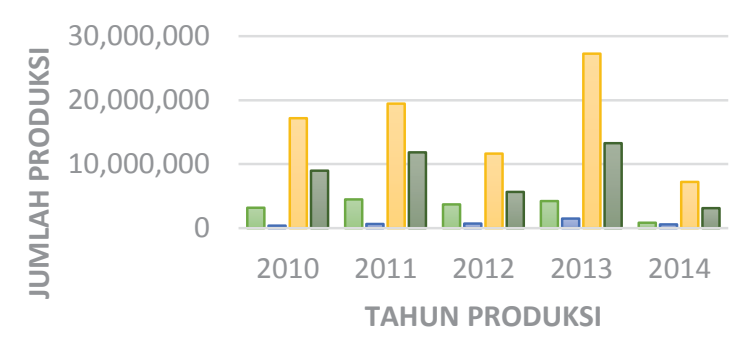

口OLIVER 72 QBEIREN $\square$ KOMORI $\square$ MITSUBISHI

Gambar 1 Jumlah Produksi Mesin Cetak Sheet

Pada proses cetak sheet terdapat beberapa mesin yaitu mesin Oliver, Beiren, Komori, dan Mitsubishi. Gambar 1 memperlihatkan jumlah produksi masing-masing mesin pada proses cetak sheet selama rentang tahun 2010 - 2014. Sedangkan untuk Gambar 2 memperlihatkan jumlah downtime (jam) masing-masing mesin cetak sheet pada tahun 2014. Kedua gambar tersebut memperlihatkan 
bahwa produksi dan downtime tertinggi terdapat pada mesin Komori LS440. Maka dari itu dibutuhkan perawatan pada mesin untuk menjaga dan meningkatkan produksi mesin serta untuk mengurangi downtime yang cukup tinggi.

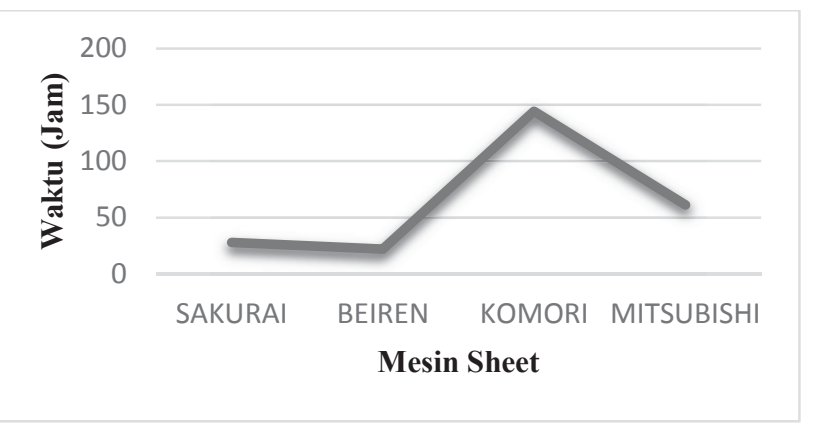

Gambar 2 Downtime Mesin Cetak Sheet 2014

Penentuan preventive maintenance pada mesin Komori LS440 menggunakan metode RCM (Reliability Centered Maintenance). Metode RCM merupakan sebuah metode yang digunakan untuk menentukan kebijakan preventive maintenance dengan menggunakan information dan decision worksheet. RCM digunakan untuk memperoleh kegiatan perawatan agar suatu aset fisik terus bekerja melakukan fungsinya sesuai konteks pengoperasiannya pada saat ini [1]. Sedangkan preventive maintenance merupakan semua tindakan yang dilakukan dalam sebuah jadwal yang terencana, periodik, dan spesifik untuk menjaga sebuah perangkat dalam kondisi operasional yang ditentukan, dengan melalui proses pemeriksaan dan rekondisi [2].

Penentuan kebijakan preventive maintenance juga memperhitungkan interval waktu perawatan. Interval waktu perawatan digunakan untuk menentukan kapan sebaiknya mesin dilakukan perawatan. Interval waktu ini dihitung berdasarkan task yang sebelumnya telah ditentukan pada decision worksheet. Selain menghitung inteval waktu kerusakan, biaya perawatan preventive maintenance juga dihitung untuk melihat berapa biaya yang dikeluarkan perusahaan jika menerapkan preventive maintenance usulan.

Metode kedua yang ada pada penelitian ini merupakan metode RBM. Metode RBM merupakan suatu metode kuantitatif yang didasarkan dari integrasi pendekatan antara reliability dan sebuah strategi pendekatan risiko yang bertujuan untuk mengoptimumkan jadwal maintenance dan untuk meminimalkan risiko yang ditimbulkan akibat failure yang terjadi [3]. Output dari metode RBM pada penelitian ini adalah nilai risiko yang ditanggung perusahaan jika sistem mengalami kegagalan fungsi.

Penelitian tentang penentuan preventive maintenance pernah dilakukan Jatnika [4]. Penelitian tersebut dilakukan penelitian di PT Perkebunan Nusantara VIII Pabrik Rancabali dengan menggunakan metode reliabiliable centered maintenance (No.11). Tujuan pada penelitian ini yaitu menentukan kebijakan perawatan, interval waktu, total biaya equipment sistem kritis di PT Perkebunan Nusantara VIII pabrik Rancabali. Metode yang digunakan yaitu metode Reliability Centered Maintenance (RCM II). Adapun untuk output dari penelitian tersebut, yaitu usulan kebijakan perawatan, interval waktu, total biaya equipment sistem kritis.

Selain penelitian yang menggunakan metode RCM II, terdapat penelitian tentang preventive maintenance dengan metode RCM II dan metode RBM yang dilakukan Noorzaman [5]. Penelitian ini dilakukan di PT Dirgantara Indonesia dengan menggunakan metode reliability centered maintenance, risk based maintenance dan marginal assurance (No. 11). Tujuan pada penlitian ini yaitu menentukan faktor-faktor yang menyebabkan tingginya downtime, kegiatan maintenance yang tepat, konsekuensi risiko yang diakibatkan kerusakan subsistem kritis, total biaya perawatan dan waktu preventive maintenance yang optimal.

\section{METODE PENELITIAN}

Pada bagian ini akan dijelaskan langkah-langkah pengerjaan dalam penelitian penentuan kebijakan perawatan.

A. Model Konseptual

Gambar 3 menunjukkan langkah-langkah pengerjaan dalam mencari preventive maintenance usulan. Sebelumnya perlu dilakukan pengumpulan data. Data yang diperlukan dalam peneliatian ini yaitu diskripsi mesin Komori LS440, kebijakan maintenance existing, data time to failure, data time to repair, data biaya komponen, data biaya material, data biaya upah engineering.

Langkah awal yang dilakukan yaitu mendiskripsikan objek penelitian. Objek pada penelitian ini merupakan mesin Komori LS440. Dalam langkah awal ini dilakukan pendeskripsian cara kerja mesin dan komponen yang terdapat pada mesin.

Langkah kedua yaitu menentukan system breakdown structure. System breakdown structure digunakan untuk mendiskripsikan sistem-sistem apa saja yang membangun mesin Komori LS440. System breakdown structure juga digunakan untuk menentukan maintenanble item yang terdpat pada mesin Komori LS440.

Langkah ketiga yaitu menentukan sistem dan subsitem kritis pada mesin Komori LS440. Penentuan dilakukan dengan menggunakan failure record system. Pemilihan ini sistem dan subsistem kritis dilakukan dengan memilih kerusakan terbanyak.

Langkah kempat yaitu menentukan functional failure yang terdapat pada mesin Komori LS440. Functional failure diambil dari tahun 2010 - 2014. Pada langkah keempat ini dilakukan analisis menggunakan metode RCM. Hasil analisis functional failure merupakan preventive task usulan.

Langkah kelima yaitu pengukuran kuantitaif dengan mengambil data Mean Time to Failure (MTTF), Mean Time to Repair (MTTR). MTTF akan dijadikan dalam perhitungan nilai reliability subsistem kritis. MTTR akan digunakan dalam menentukan biaya perawatan subsistem.

Dalam menentukan MTTF dan MTTR (No .12) terlebih dahulu dilakukan plotting distribusi pada data TTF dan data TTR. Distribusi yang digunakan untuk failure yaitu distribusi eksponensial, distribusi normal, dan distribusi weibull. Setelah mendapatkan distribusi yang sesuai kemudian dilakukan penentuan parameter yang mewakili distribusi. Jika sudah ditentukan ditentukan parameter kemudian dilakukan perhitungan untuk miencari MTTF dan MTTR. 
Langkah keenam dilakukan penentuan interval waktu perawatan. Interval waktu ini merupakan interval waktu perawatan kegiatan preventive maintenance.

Langkah ketujuh dilakukan perhitungan untuk melihat berapa biaya yang dikeluarkan untuk melakukan kegiatan preventive maintenance usulan dan untuk melihat apakah kegiatan preventive maintenance usulan layak atau tidak untuk diimplementasikan.

Langkah selanjtunya yaitu menentukan berapa besar nilai yang dikeluarkan oleh perusahaan ketika mesin mengalami kegagalan fungsi. Nilai risiko ini juga menentukan apakah perusahaan masih bisa mentoleransi kegagalan fungsi yang didapat. Jika tidak dapat diterima, maka dilakukan kegiatan preventive maintenance usulan untuk mengurangi risiko kegagalan fungsi mesin Komori LS440.

Langkah terakhir, yaitu menentukan kebijakan preventive maintenance dengan mempertimbangkan nilai risiko kegagalan fungsi, biaya kegiatan preventive maintenance usulan, dan dengan memeprtimpangkan interval waktu perawatan serta melihat maintenance task yang telah dilakukan ananlisis sebelumnya.

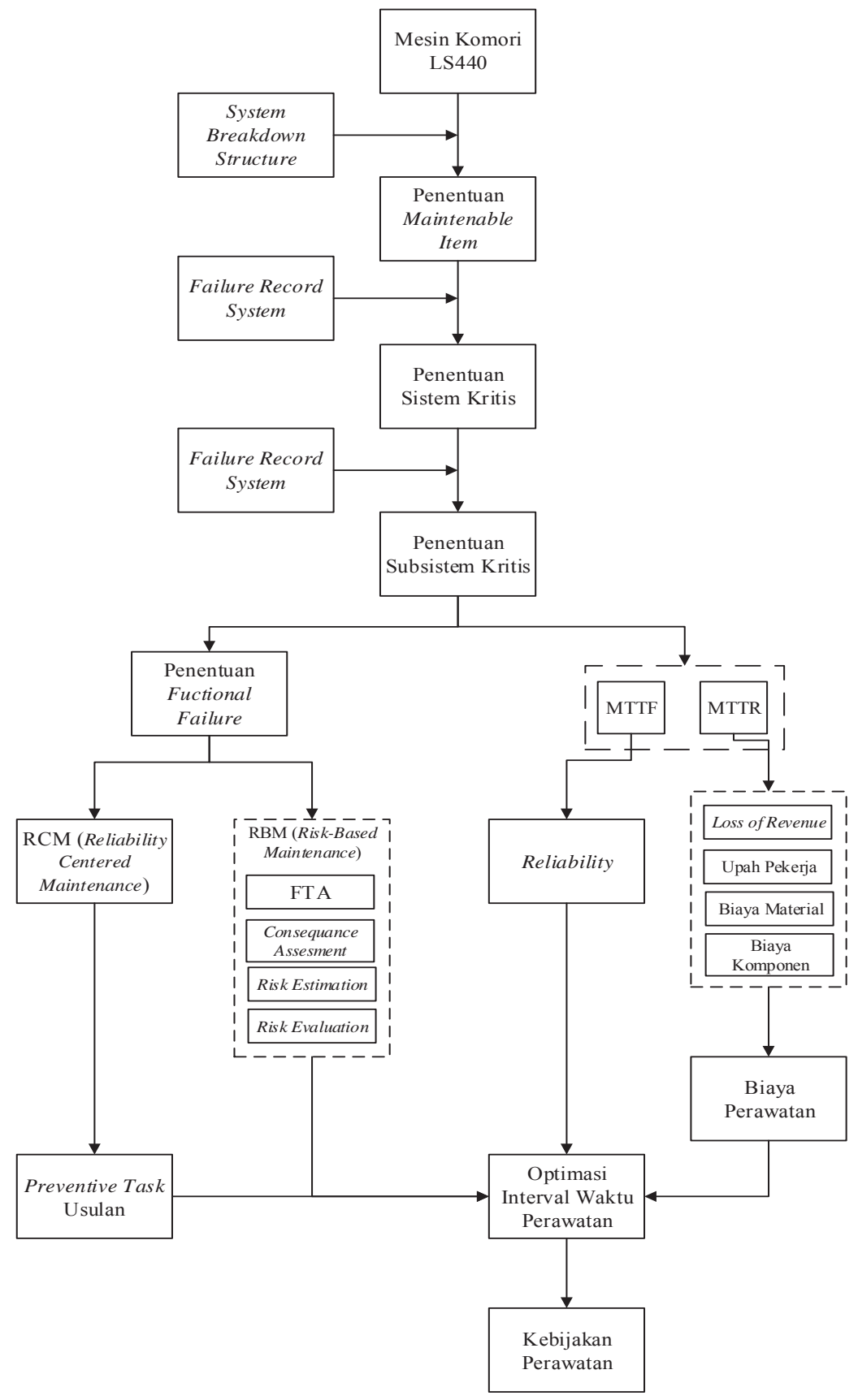

Gambar 3 Model konseptual 


\section{HASIL DAN PEMBAHASAN}

A. Pemilihan Sistem dan Subsistem Kritis

Pemilihan sistem dan subsistem kritis bertujuan untuk menfokuskan cakupan penelitian. Pemilihan sistem dan subsistem kritis menggunakan failure record system. Mesin Komori LS440 terdiri dari tiga sistem yaitu sistem eletronik, chiller dan mekanik. Tabel I menunjukkan sistem-sistem yang ada di mesin Komori LS440 dengan jumlah failure yang terjadi selama tahun 2010 - 2014.

Berdasarkan Tabel I dapat diketahui bahwa sistem kritis pada mesin Komoril LS440 merupakan sistem mekanik. Pemilihan ini berdasarkan jumlah kerusakan sistem mekanik sebesar 45 kerusakan atau $82 \%$ dari total kerusakan. Sistem mekanik terdiri dari beberapa subsistem pendukung, yaitu subsistem feeder, printing, dan delivery. Pada Tabel II dapat diketahui bahwa subsistem kritis terdapat pada subsitem feeder. Pemilihan ini berdasarkan jumlah kerusakan subsistem feeder yang cukup tinggi yaitu sebanyak 24 kerusakaan atau 44\%.

TABEL I

FREKUENSI KERUSAKAN SISTEM KOMORI LS440

\begin{tabular}{|l|c|c|}
\hline \multicolumn{1}{|c|}{ Sistem } & Jumlah kerusakan & Persen kerusakan \\
\hline Elektronik & 7 & $13 \%$ \\
\hline Mekanik & 45 & $82 \%$ \\
\hline Chiller & 3 & $5 \%$ \\
\hline Total & 55 & \\
\cline { 1 - 2 } & &
\end{tabular}

TABEL II

FREKUENSI KERUSAKAN SUBSISTEM KOMORI LS440

\begin{tabular}{|l|c|c|}
\hline \multicolumn{1}{|c|}{ Sistem } & Jumlah kerusakan & Persen kerusakan \\
\hline Elektronik & 24 & $44 \%$ \\
\hline Mekanik & 20 & $36 \%$ \\
\hline Chiller & 1 & $2 \%$ \\
\hline Total & 45 & \\
\cline { 1 - 2 } & &
\end{tabular}

\section{B. Pengukuran Kualitatif Menggunakan RCM}

Pengukuran kualitatif menggunakan metode RCM dilakukan untuk menentukan apa saja kebutuhan maintenance pada subsistem penyusun sistem kerja Komori LS440. Hasil pengukuran menggunakan RCM dapat dilihat pada Tabel V khusunya pada kolom task usulan.

1. Fungsi Sistem dan Kegagalan Fungsional

Mesin Komori LS440 terdiri dari beberapa subsistem mekanik yang saling berhubungan satu subsistem dengan subsitem yang lain. Subsistem yang ada memiliki fungsi berbeda-beda yang mendukung kinerja satu sama lain agar mesin dapat bekerja dengan baik. Sedangkan kegagalan fungsional merupakan kegagalan yang terjadi pada mesin selama waktu beroperasi.

2. Failure Mode and Effect Analysis (FMEA)

FMEA menjelaskan penyebab kegagalan serta dampak yang ditimbulkan akibat kegagalan tersebut. Sebagai contoh dapat dilihat pada Tabel VI, kerusakan pertama yang terjadi pada sucker feeder merupakan bearing berkarat. Bearing berkarat merupakan failure mode atau penyebab kegagalan, sedangkan efeknya merupakan unit feeder berisik (No.13).

3. Logic Tree Ananlysis (LTA)

Logic Tree Analylis digunakan untuk mengklasifikasikan konsekuensi modus kegagalan. Modus kegagalan ini menggunakan Decision Worksheet [1]. Modus kegagalan dikategorikan dalam empat mode, yaitu Hidden Failure $(\mathrm{H})$, Safety Consequences (S), Environmental Consequences (E), dan Operational Consequences (O). Hidden Failure merupakan sebuah modus kegagalan yang tersebunyi pada saat keadaan normal oleh operator. Safety Consequences merupakan modus kegagalan yang berhubungan dengan keselamatan operator. Enviromental Consequences merupakan modus kegagalan yang berhubungan dengan lingkungan. Operational Consequences merupakan modus kegagalan yang memberikan konsekuensi operasional. Setiap komponen akan dilihat apakah terdapat konsekuensi kegagalan. Analisis dengan menggunakan LTA dapat dilihat pada lampiran A (No.13).

4. Preventive Task Selection

Preventive Task terdiri dari tiga alternatif, yaitu scheduled on condition task, scheduled restoration task, dan scheduled discard task. Pemilihan ketiga alternatif ini berdasarkan analisis yang terdat pada RCM Decision Logic.

Kolom preventive task memiliki beberapa simbol yang menunjukkan alternatif masing-masing task H1S1O1N1 menunjukkan bahwa task yang harus dilakukan yaitu scheduled on condition task jika H2 S2 O2 N2 menunjukkan bahwa task yang harus dilakukan yaitu scheduled restoration task sedangkan H3 S3 O3 N3 menunjukkan bahwa task yang harus dilakukan yaitu scheduled discard task. Hasil Analisis dengan menggunakan Preventive Task dapat dilihat pada lampiran A.

\section{Perhitungan MTTF dan MTTR}

Sebelum menghitung MTTF dan MTTR, maka terlebih dahulu melakukan pengujian distribusi terhadap waktu failure (TTF) dan waktu repair (TTR) masing-masing komponen. Pengujian ini dilakukan dengan menggunakan software MiniTab 17. Setelah mendapatkan jenis distribusi masingmasing komponen, kemudian ditentukan parameter masingmasing distribusi dengan menggunakan software Avsim+ 9.0. Setelah mengetahui distribusi dan parameter untuk setiap komponen, kemudian dilakukan perhitungan untuk mengetahui MTTF dan MTTR masing-masing komponen. Jika komponen berdistribusi eksponensial dan normal, maka MTTF dan MTTR ditentukan dengan nilai paremater $\mu$. Namun jika komponen berdistribusi weibull maka menggunakan rumus:

$$
\text { MTTF/MTTR }=\eta \Gamma\left(1+\frac{1}{\beta}\right), \Gamma(x)=\text { tabel Gama }
$$

Tabel III merupakan hasil perhitungan MTTF pada masingmasing komponen kritis. Perhitungan ini dilakukan sesuai dengan distribusi dan nilai parameter masing-masing, sedangkan Tabel IV menunjukkan hasil perhitungan MTTR pada masing-maisng komponen kritis. Cara perhitungan MTTR dan MTTF sama yaitu dengan menyesuaikan distribusi dan nilai parameter. 
D. Penentuan Maintenance Task dan Perhitungan Waktu Interval Perawatan

Penentuan maintenance task dilakukan dengan menganalisis information worksheet dan decision worksheet [1]. Analisis pada information worksheet dilakukan dengan mengamati record failure. Tabel information worksheet terdiri dari fungsi sistem, kegagalan sistem dan FMEA (Failure Mode and Effect Analysis).

TABEL III

NILAI PARAMETER DAN MTTF KOMPONEN KOMORI LS440

\begin{tabular}{|c|c|c|c|c|}
\hline \multirow{2}{*}{ Komponen } & Distribusi & \multicolumn{2}{|c|}{ Parameter } & $\begin{array}{c}\text { MTTF } \\
\text { (Jam) }\end{array}$ \\
\hline $\begin{array}{c}\text { Sucker } \\
\text { Feeder }\end{array}$ & Weibull & $\eta$ & 3749,17 & \multirow{2}{*}{3349,958} \\
\cline { 3 - 4 } & & $\mu$ & 1,06067 & \\
\hline $\begin{array}{c}\text { Rantai Meja } \\
\text { Feeder }\end{array}$ & Normal & $\sigma$ & 4722,96 & \multirow{2}{*}{4722,96} \\
\cline { 3 - 4 } & & $\eta$ & 1470,48 & \multirow{2}{*}{2087,876} \\
\hline $\begin{array}{c}\text { Solenoid } \\
\text { Feeder }\end{array}$ & Weibull & $\beta$ & 0,629688 & \\
\cline { 3 - 4 } & & \multicolumn{2}{|c|}{} & \\
\hline
\end{tabular}

TABEL IV

NILAI PARAMETER DAN MTTR KOMPONEN KOMORI LS440

\begin{tabular}{|c|c|c|c|c|}
\hline \multirow{2}{*}{ Komponen } & Distribusi & \multicolumn{2}{|c|}{ Parameter } & $\begin{array}{c}\text { MTTF } \\
\text { (Jam) }\end{array}$ \\
\hline \multirow{2}{*}{$\begin{array}{c}\text { Sucker } \\
\text { Feeder }\end{array}$} & Weibull & $\eta$ & 4,26513 & \multirow{2}{*}{3,80633} \\
\cline { 3 - 4 } & $\beta$ & 1,69144 & \\
\hline $\begin{array}{c}\text { Rantai Meja } \\
\text { Feeder }\end{array}$ & Eksponensial & $\mu$ & 2,85417 & \multirow{2}{*}{2,85417} \\
\cline { 3 - 4 } & $\varepsilon$ & 0,080395 & \\
\hline \multirow{2}{*}{$\begin{array}{c}\text { Solenoid } \\
\text { Feeder }\end{array}$} & Eksponesial & $\mu$ & 3 & \multirow{2}{*}{3} \\
\cline { 3 - 4 } & & $\varepsilon$ & 0,098837 & \\
\hline
\end{tabular}

Setelah mendapatkan information worksheet dari record failure kemudian dapat ditentukan decision worksheet. Tabel decisioan worksheet berisi Logic Tree Ananlysis (LTA) dan preventive task. Hasil dari decision worksheet yaitu maintenance task untuk masingmasing komponen kritis. Miantenance task hasil decision worksheet ada tiga jenis, yaitu schedule on condition task, scheduled restoration task dan scheduled discard task. Analisis decision worksheet dilakukan dengan digram keputusan RCM [1].

Hasil maintenance task yang telah ditentukan kemudian akan ditentukan interval waktu yang tepat untuk melakukan perawatan. Perhitungan interval waktu ini tergantung pada jenis task yang ada pada komponen. Rumus untuk menghitung interval perawatan schedule on condition task yaitu [1]

$\mathrm{PM}=1 / 2 \times \mathrm{P}-\mathrm{F}$ Interval

Adapun untuk rumus yang digunakan pada scheduled restoration task dan scheduled discard task yaitu dengan dilakukan perhitungan biaya perbaikan atau penggantian kerusakan komponen. Rumus yang digunakan yaitu sebagai berikut.
$\mathrm{Cf}=\mathrm{Cr}+\mathrm{MTTR}(\mathrm{Co}+\mathrm{Cw})$

$\mathrm{Cf} \quad=$ Biaya perbaikan atau penggatian karena kerusakan komponen setiap siklus perawatan

$\mathrm{Cr} \quad=$ Biaya penggantian kerusakan komponen

$\mathrm{Co} \quad=$ Biaya kerugian produksi (loss revenue)

$\mathrm{Cw}=$ Biaya tenaga kerja $\mathrm{Cf}$ (Biaya perbaikan), kemudian dilakukan perhitungan untuk menghitung biaya yamg dikeluarkan

Setelah mendapatkan nilai untuk melakukan perawatan (Cm) yaitu dengan menjulahkan biaya downtime + tenaga kerja + biaya perbaikan. Jika nilai $\mathrm{Cf}$ dan $\mathrm{Cm}$ diketahuin maka dapat dilakukan perhitungan untuk menentukan interval waktu yang tepat untuk kegiatan maintenance. Rumus penentuan interval waktu pada setiap masing-masing task dapat dilihat pada persamaan 4 .

$\left.T M=\eta x\left(\frac{C m}{C f(\beta-1)}\right)^{\frac{1}{\beta}}\right)$

Tabel V menunjukkan hasil penentuan maintenance task disetiap masing-masing kerusakan. Serta Tabel V menunjukkan interval waktu untuk melakukan maintenance task tersebut. Sebagai contoh pada komponen sucker feeder yang memiliki miantenance task scheduled on condition, perawatan seharusnya dilakukan setiap $1.829,78$ jam sekali untuk menjaga reliabilitas komponen tersebut.

TABEL V

HASIL PENENTUAN TASK DAN PERHITUNGAN INITIAL INTERVAL

\begin{tabular}{|c|c|c|c|c|}
\hline No. & Komponen & Task Usulan & $\begin{array}{l}\text { MTTF } \\
\text { (Hours) }\end{array}$ & $\begin{array}{c}\text { Initial } \\
\text { Interval } \\
\text { (Hours) }\end{array}$ \\
\hline \multirow{6}{*}{1} & \multirow{6}{*}{$\begin{array}{l}\text { Sucker } \\
\text { Feeder }\end{array}$} & $\begin{array}{l}\text { Scheduled on } \\
\text { Condition }\end{array}$ & \multirow{6}{*}{3349,96} & 1829,78 \\
\hline & & Scheduled Discard & & $2,183,127$ \\
\hline & & Scheduled Discard & & $2,212,905$ \\
\hline & & Scheduled Discard & & $2,230,536$ \\
\hline & & $\begin{array}{l}\text { Scheduled on } \\
\text { Condition }\end{array}$ & & 1829,78 \\
\hline & & Scheduled Discard & & $2,210,262$ \\
\hline \multirow{3}{*}{2} & \multirow{3}{*}{$\begin{array}{c}\text { Rantai } \\
\text { Meja } \\
\text { Feeder }\end{array}$} & $\begin{array}{l}\text { Scheduled on } \\
\text { Condition }\end{array}$ & \multirow{3}{*}{4722,96} & 2361,48 \\
\hline & & $\begin{array}{l}\text { Scheduled } \\
\text { Restoration }\end{array}$ & & $2,953,570$ \\
\hline & & Scheduled Discard & & $2,883,858$ \\
\hline \multirow{6}{*}{3} & \multirow{6}{*}{$\begin{array}{l}\text { Solenoid } \\
\text { Feeder }\end{array}$} & $\begin{array}{l}\text { Scheduled on } \\
\text { Condition }\end{array}$ & \multirow{6}{*}{2087,88} & 2922,15 \\
\hline & & $\begin{array}{l}\text { Scheduled on } \\
\text { Condition }\end{array}$ & & 2922,15 \\
\hline & & Scheduled Discard & & $1,363,666$ \\
\hline & & $\begin{array}{l}\text { Scheduled on } \\
\text { Condition }\end{array}$ & & 2922,15 \\
\hline & & $\begin{array}{l}\text { Scheduled } \\
\text { Restoration }\end{array}$ & & $1,374,753$ \\
\hline & & $\begin{array}{l}\text { Scheduled } \\
\text { Restoration }\end{array}$ & & $1,374,756$ \\
\hline
\end{tabular}

E. Perhitungan Biaya Perawatan

Perhitungan biaya perawatan dihitung dari perawatan usulan yang telah ditentukan sebelumnya. Perhitungan ini dilakukan dengan menggunakan rumus [6] 
$\mathrm{Tc}=\left(\mathrm{C}_{\mathrm{M}}+\mathrm{Cr}\right) \times \mathrm{f}_{\mathrm{M}}$

$\mathrm{C}_{\mathrm{M}}=$ biaya yang dikeluarkan untuk perawatan

$\mathrm{Cr}=$ biaya komponen

$\mathrm{f}_{\mathrm{M}}=$ frekuensi pelaksanaan preventive maintenance

Hasil perhitungan, biaya yang dikeluarkan untuk melakukan kegiatan preventive maintenance eksisiting yang dilakukan dalam kurun waktu tiga bulan sekali yaitu sebesar Rp1.242.004.320,00, sedangkan untuk kegiatan preventive maintenance usulan yang dilakukan seperti task yang telah dihitung didapatkan nilai sebesar Rp971.567.519,69. Biaya preventive maintenance usulan lebih rendah daripada preventive maintenance eksisiting menunjukkan interval waktu yang dikeluarkan untuk kegiatan preventive maintenance usulan lebih optimal.

\section{F. Perhitungan Risiko RBM}

Perhitungan risiko dilakukan dengan menggunakan metode RBM. Risiko ini merupakan risiko yag diterima perusahaan ketika mesin mengalami kegagalan. Langkah pertama dalam menentukan berapa besar yang ditanggung perusahaan yaitu dengan menyusun skenario kegagalan. Skeneario kegagalan merupakan skenario untuk masingmasing komponen yang memperlihatkan failure mode dan failure effect. Setelah menyusun skenario kegagalan, kemudian ditentukan seberapa besar nilai kegagalan tersebut.

TABELVI

SKENARIO KEGAGALAN DAN NORMALISASINYA

\begin{tabular}{|c|c|c|c|}
\hline Komponen & \multicolumn{2}{|r|}{ Skenario Kegagalan } & \multirow{2}{*}{$\begin{array}{c}\text { Normalisasi } \\
\text { Konsekuensi } \\
5\end{array}$} \\
\hline \multirow{6}{*}{$\begin{array}{l}\text { Sucker } \\
\text { Feeder }\end{array}$} & 1 & $\begin{array}{l}\text { Bearing berkarat, Unit feeder } \\
\text { berisik }\end{array}$ & \\
\hline & 2 & $\begin{array}{l}\text { Pully penggerak patah, Hisapan } \\
\text { vacum kurang maksimal }\end{array}$ & 8 \\
\hline & 3 & $\begin{array}{l}\text { Kompresor vacum patah, As kopel } \\
\text { tidak berputar }\end{array}$ & 8 \\
\hline & 4 & $\begin{array}{l}\text { Bearing vacum aus dan kotor, } \\
\text { Sucker feeder tidak menghisap }\end{array}$ & 9 \\
\hline & 5 & $\begin{array}{l}\text { Filter pump kotor, Vacum tidak } \\
\text { menghisap kertas }\end{array}$ & 9 \\
\hline & 6 & $\begin{array}{l}\text { Carbon blade rusak, Pump tidak } \\
\text { bekerja normal }\end{array}$ & 8 \\
\hline & 1 & $\begin{array}{l}\text { Dudukan sensor bergetar, Kertas } \\
\text { tidak jalan }\end{array}$ & 8 \\
\hline $\begin{array}{l}\text { Rantai } \\
\text { Meja } \\
\text { Feeder }\end{array}$ & 2 & $\begin{array}{l}\text { Guide tidak terbuka, Kertas sobek } \\
\text { ketika diambil oleh gripper }\end{array}$ & 9 \\
\hline & 3 & $\begin{array}{l}\text { Guide separator drive bengkok, } \\
\text { Kertas berhenti di rantai meja }\end{array}$ & 8 \\
\hline \multirow{6}{*}{$\begin{array}{l}\text { Solenoid } \\
\text { Feeder }\end{array}$} & 1 & Sensor kotor, Double sheet & 7 \\
\hline & 2 & $\begin{array}{l}\text { Timing berubah, Sidelay tidak pada } \\
\text { posisi seharusnya }\end{array}$ & 7 \\
\hline & 3 & $\begin{array}{l}\text { Bushing selang keropos, Jalan } \\
\text { kertas tidak lancar }\end{array}$ & 8 \\
\hline & 4 & $\begin{array}{l}\text { Cam dan camfollower gripper tidak } \\
\text { tersetting, Jalan kertas tidak lancar }\end{array}$ & 7 \\
\hline & 5 & $\begin{array}{l}\text { Sensor mati, Cetak bukan pada } \\
\text { tempatnya }\end{array}$ & 7 \\
\hline & 6 & $\begin{array}{l}\text { Gripper dan run deterctor eror, } \\
\text { Terjadi double sheet }\end{array}$ & 7 \\
\hline
\end{tabular}

Tabel VI memperlihatkan berapa nilai setiap masingmasing kerusakan. Rentang nilai pada normalisasi kerusakan yaitu dari $0-10$. Nilai nol merupakan kerusakan yang tidak menyebabkan pengaruh terhadap kegiatan operasional perusahaan. Akan tetapi, sepuluh merupakan nilai tertinggi yang berarti dengan adanya kerusakan tersebut dapat menghentikan proses produksi pada perusahaan.

Langkah ketiga dalam menentukan risiko yaitu dilakukan dengan menggunakan probabilistic hazard assesment yang dilakukan dengan metode fault tree analysis. Fault tree analysis merupakan gambaran skenario kerusakan yang mungkin terjadi pada subsistem kritis. Hasil analisis fault tree analysis dapat dilihat pada Lampiran B.

Langkah selanjutnya yaitu dilakukan dengan quantitative hazard assesment. Hal pertama yang dilakukan yaitu dengan menghitung system performance loss dengan cara (Waktu Donwtime x Loss Production) + (Mean Time To Repair $x$ Engineer cost) + Material cost + Harga Komponen [3]

TABEL VII

NILAI SYSTEM PERFORMANCE LOSS

\begin{tabular}{|c|c|cc|}
\hline No. & Komponen & \multicolumn{2}{|c|}{ System Performance Loss } \\
\hline 1 & Sucker Feeder & $\mathrm{Rp}$ & $104.339 .266,59$ \\
\hline 2 & Rantai Meja Feeder & $\mathrm{Rp}$ & $942.371 .606,01$ \\
\hline 3 & Solenoid Feeder & $\mathrm{Rp}$ & $104.257 .408,00$ \\
\hline
\end{tabular}

Tabel VII merupakan hasil perhitungan untuk mendapatkan system performance loss. Setelah mendapatkan nilai system performance loss, kemudian dilakukan perhitungan untuk mencari probabilitas kerusakan setiap komponen kritis $(\mathrm{Q}(\mathrm{T}))$ dengan persamaan kepadatan probabilitas. Kemudian untuk mendapatkan nilai risiko untuk masing-masing komponen dilakukan perhitungan dengan cara mengkalikan system performance loss $\mathrm{x} Q \mathrm{Q}(\mathrm{T})$. Tabel VIII merupakan hasil perhitungan risiko yang ditanggung PT ABC untuk kerusakan pada setiap subsistem kritis tanpa adanya kegiatan preventive maintenance. Nilai yang ditanggung yaitu sebesar Rp965.904.899,36.

TABEL VIII

PERHITUNGAN RISIKO

\begin{tabular}{|c|l|c|c|c|}
\hline No. & $\begin{array}{l}\text { Kompo } \\
\text { nen }\end{array}$ & $\begin{array}{c}\text { System } \\
\text { Performance Loss }\end{array}$ & Q(T) & Risk \\
\hline 1 & $\begin{array}{l}\text { Sucker } \\
\text { Feeder }\end{array}$ & Rp 104.339.266,59 & $\begin{array}{c}0,98331 \\
6\end{array}$ & Rp 102.598.426,29 \\
\hline 2 & $\begin{array}{l}\text { Rantai } \\
\text { Meja } \\
\text { Feeder }\end{array}$ & Rp 942.371.606,01 & 0,81057 & $\operatorname{Rp~763.858.152,68~}$ \\
\hline 3 & $\begin{array}{l}\text { Solenoi } \\
\text { Feeder }\end{array}$ & Rp 104.257.408,00 & $\begin{array}{c}0,95387 \\
3\end{array}$ & $\operatorname{Rp~99.448.320,39~}$ \\
\hline \multicolumn{4}{|c|}{ Total } & Rp 965.904.899,36 \\
\hline
\end{tabular}

Risiko sebesar Rp 965.904.899,36 dirasa cukup besar oleh PT $\mathrm{ABC}$, kerena dengan nilai sebesar itu dapat menjadi penghasilan akan sangat menguntungkan perusahaan. Oleh sebab itu dilakukanlah perancangan penerimaan risiko untuk mengetahui 
apakah nilai risiko sebesar Rp 965.904.899,36 masih dapat diterima perusahaan.

Penerimaan risiko yang dapat diterima perusahaan hanya sebesar $0,75 \%$ dari kapasitas produksi. Nilai sebesar $0,75 \%$ merupakan nilai risiko untuk masing-masing sistem mesin Komori LS440. Kapasitas produksi mesin dihitung dari nilai hourly rate selama satu tahun.

$$
\begin{aligned}
& \text { Periode } 1 \text { tahun }=24 \text { jam } \times 22 \text { hari } \times 12 \text { bulan } \\
& =6336 \mathrm{jam} \\
& \text { Hourly rate } \quad=\quad \mathrm{Rp} \mathrm{19.400.000,00} \\
& \text { Kapasitas } \quad=\operatorname{Rp~} 19.400 .000,- \text { x } 6336 \\
& =\operatorname{Rp} 122.918 .400 .000,- \\
& \text { Total Risiko } \quad=\quad \operatorname{Rp} 965.904 .899,36 \\
& \text { Presentase } \quad=\text { Total Risiko / kapasitas produksi } \\
& \text { Rp 965.904.899,36 / Rp } \\
& =122.918 .400 .000 \text {,- } \\
& =0,79 \%>0,75 \%
\end{aligned}
$$

Dari hasil perhitungan didapatkan bahwa presentase total risiko yang ditanggung $\mathrm{PT} \mathrm{ABC}$ jika tidak menjalankan kegiatan preventive maintenance akan memberikan risiko sebesar $0,79 \%$ sedangkan failure yang diterima oleh perusahaan yaitu sebesar $0,75 \%$ untuk sistem mekanik.

\section{KESIIMPULAN}

Berdasarkan analisis dan pengukuran pada penelitian ini didapatkan preventive maintenance yang tepat untuk komponen yang terdapat pada subsistem kritis, yaitu komponen Sucker Feeder yaitu Scheduled on Condition Task (dilakukan setiap 3,5 bulan sekali) dan Scheduled Discard Task (dilakukan setiap 4 bulan sekali), komponen Rantai Meja Feeder yaitu Scheduled on Condition Task (dilakukan setiap 4,5 bulan sekali), Scheduled Restoration Task (dilakukan setiap 5,5 bulan sekali), dan Scheduled Discard Task (dilakukan setiap 5,5 bulan sekali), dan komponen solenoid Feeder yaitu Scheduled on Condition Task (dilakukan setiap 5,5 bulan sekali), Scheduled Restoration Task (dilakukan setiap 2,6 bulan sekali), dan Scheduled Discard Task (dilakukan setiap 2,5 bulan sekali). Kegiatan preventive maintenance ini membutuhkan biaya sebesar Rp 971.567.519,69. Sedangkan pengolahan dengan metode RBM didapatkan nilai risiko yang diterima PT ABC jika mesin mengalami kerusakan yaitu sebesar Rp 965.904.889,36.

\section{DAFTAR PUSTAKA}

[1] Moubray, J. (1991). Reliability Centered Maintenance II. Oxford: Butterworth-Heineman,Ltd.

[2] Dhillon, B. S. (2002). Engineering Maintenance "A Modern Approach". New York: CRC Process LLC.

[3] Khan, F., \& Haddara, M. (2004). Risk-Based Maintenance (RBM) : A New Approach for Process Plant Inspection and Maintenance. Process Safety Progress, 252-264.
[4] Jatnika, M. (2015). Perancangan Usulan Perawatan Mesin Teh Hitam Orthodoks Menggunakan Metode Reliabiliable Cetered Maintenance Di PT Perkebunan Nusantara VIII Pabrik Rancabali. Bandung: Telkom University.

[5] Noorzaman, H. (2011). Optimasi Preventive Maintenance dan Pengadaan Komponen Kritis Mesin Toshiba BMC100(5) dengan Menggunakan Metode Reliability Centered Maintenance, Risk Based Maintenance dan Marginal Assurance di PT Dirgantara Indonesia. Bandung: Telkom University.

[6] Harvard, T. (2000). Determine of a Cost Optimal, Predetermined Maintenance Schedule. 